\title{
Effects of grain sources and feeding methods, free- choice vs total mixed ration, on milk yield and composition of German Fawn x Hair crossbred goats in mid lactation*
}

\author{
S. Yurtseven and M. Görgülü̈ ${ }^{1}$ \\ Çukurova University, Agricultural Faculty, \\ Department of Animal Science \\ 01330 Adana, Turkey
}

(Received 3 October 2003; revised version 11 May 2004; accepted 16 June 2004)

\begin{abstract}
The present study was designed to: 1 . test whether lactating goats could select a nutritionally adequate diet when offered an unrestricted choice among feed ingredients, 2. asses whether the goats change their diet preferences according to the source of grain and, 3. determine whether the choice feeding compared with a TMR would alter the lactating performance and also milk composition of German Fawn $\times$ Hair crossbred goats during mid lactation. A total 36 goats was allocated to 4 experimental groups with three replicates, comprising three goats each for a 9-week-period, including one week training period for choice-fed goats. The treatment groups were: 1. ad libitum total mixed ration with barley (BTMR; containing 40\% lucerne hay and 60\% concentrate consisted of ground barley, soyabean meal and wheat bran); 2. choice feeding (BCF) among the feed ingredients of the BTMR; 3. ad libitum total mixed ration with maize grain (MTMR; containing $40 \%$ lucerne hay and $60 \%$ concentrate consisted of ground maize, soyabean meal and wheat bran); 4. choice feeding (MCF) among the feed ingredients of the MTMR.

The results showed that feeding method had significant effects on dry matter (DMI; $\mathrm{P}<0.06$ ), crude fibre $(\mathrm{P}<0.01), \mathrm{ADF}$ and NDF intakes $(\mathrm{P}<0.01)$, but grain source and the interaction of factors had no significant effects on nutrient intake, milk yield and liveweight change. Milk composition was not affected by feeding methods, grain sources and their interaction. The diet selected by goats in $\mathrm{MCF}$ and $\mathrm{BCF}$ contained less lucerne, but more wheat bran than their corresponding TMRs. The selected diets had higher metabolizable energy, less CF, ADF and NDF than the TMRs. Grain sources also had significant effects on diet selection by goats; the diet selected in BCF had
\end{abstract}

\footnotetext{
* Supported by Çukurova University Research Fundation

${ }^{1}$ Corresponding author: e-mail: gorgulu@cu.edu.tr
} 
higher fibre than those selected in MCF. It was concluded that lactating goats can select their diet according to their nutrient requirements when they are given choice among feed ingredients. It was also concluded that the goats could consume high level concentrate (75-77\%) without having any metabolic problem and they could shift their selection according to the grain source and also the period of experiment.

KEY WORDS: choice-feeding, diet selection, goat, milk yield, milk composition, German Fawn $\times$ Hair crossbred goat

\section{INTRODUCTION}

Stall feeding practice for high yielding dairy goats includes two options, which are feeding high amount of concentrate during milking separately from roughage given ad libitum, and the use of TMR containing high level of concentrate (e.g., $60 \%$ or over). Increasing concentrate level in the diet improves nutritional status of goats by increasing energy, protein, mineral and vitamin supply and optimizes the feed efficiency for growth, gestation or milk production (Cerillo et al., 1999). However, loading rumen with high amount of concentrate twice a day or with TMR containing high amount of concentrate may reduce digestibility of dietary fibre (Galyean and Owen, 1991; Archimede et al., 1995).

It is well known that the degradation rate of cereal starch is quite different (e.g., maize starch less degradable than barley starch, as reported by Herrera-Saldana et al., 1990; Petit, 2000) and different grain sources may modify ruminal fermentation pattern (Schmidely et al., 1999). Especially, when the animal consumes high amount of concentrate, low ruminal $\mathrm{pH}$ may reduce fibre digestion, microbial growth and milk fat (Santini et al., 1992). Offering feed ingredients to animal as choice could have a potential to overcome these problems. Recent studies (Fedele et al, 2002; Görgülü et al., 2003) showed that goats can select their diet according to their nutrient requirements, and also can consume high amount of concentrate without suffering any digestive problem by balancing fibre intake. The same authors also suggested that animals having free access to multiple choices had opportunities to create synchronization of energy and nitrogen supply to the rumen. In addition, comparing TMR, increase in daily gain in lambs (Görgülü et al., 1996) and in milk yield in goats (Görgülü et al., 2003) was reported when feed ingredients were offered as choice.

However, there is no information in the present literature whether diet preferences of goats would change according to grain sources differing in starch degradability. The present study was, therefore, aimed to: 1 . test whether lactating goats can select a nutritionally balanced diet to meet their nutrient requirement when offered an unrestricted choice of diet ingredients used in TMRs; 2 . asses whether the goats change their diet preferences according to the source of grain; 3. determine whether the choice 
feeding compared with TMR would alter the lactating performance and also milk composition of German Fawn $\times$ Hair crossbred goats during mid lactation.

\section{MATERIAL AND METHODS}

The study was conducted from May to July, 2002 in the Goat Unit (a semi open barn) of Agricultural Faculty Farm, University of Cukurova, Adana (Turkey). Thirty six German Fawn $\times$ Hair crossbred goats, having twin kids, in the second lactation were used in the study. The goats, $102 \pm 13$ days after postpartum, were allocated into four experimental groups with tree replicates, comprising three goats each in a $1.5 \mathrm{~m} \times 3 \mathrm{~m}$ pen. Each pen of TMR groups had one feeder sizing $0.4 \mathrm{~m} \times 2 \mathrm{~m}$ with a 15 -L bucket for fresh water. The feeder of the choice fed groups was divided into four equal parts to supply feed ingredients separately. The goats were assigned to the treatments according to the liveweight and daily milk yield.

The experiment was carried out according to $2 \times 2$ factorial arrangement (two grain sources and two feeding methods) in a completely randomized design. The treatment groups were: 1. ad libitum total mixed ration with barley (BTMR), containing $40 \%$ lucerne hay having $1-2 \mathrm{~cm}$ particle size and $60 \%$ concentrate (as fed) consisted of ground barley, soyabean meal and wheat bran (Table 1); 2. choice feeding (BCF) among the feed ingredients of the BTMR given ad libitum; 3. ad libitum total mixed ration with maize grain (MTMR), containing $40 \%$ lucerne hay and $60 \%$ concentrate consisted of ground maize, soyabean meal and wheat bran (Table 1); 4. choice feeding (MCF) among the feed ingredients of the CTMR given ad libitum.

The experiment, including a one-week-training period at the beginning for the choice-fed groups, lasted for 9 weeks. During the training period for choice feeding groups, the three ingredients of concentrate, wheat bran, grain sources (barley or maize) and soyabean meal along with lucerne hay were supplied in the first, second and third days of the training period, respectively. The same procedure was applied for the next three days, and the last day of training week and throughout the experimental period, all ingredients were offered simultaneously. TMR groups were fed with their own TMRs during training period.

Each of the feed ingredients, except lucerne hay, given to choice feeding groups separately was mixed with mineral-vitamin premix, salt and limestone at the levels used in the concentrate of the TMRs in order to ensure the micronutrients intakes of choice-fed goats and also to prevent any possible effect of micronutrients on diet selection. Fresh water was available freely during the entire experimental period for all animals. 
TABLE 1

Compositions of TMR and the diets selected by choice fed goats, $\mathrm{g} / \mathrm{kg}$, as fed

\begin{tabular}{|c|c|c|c|c|c|c|c|c|}
\hline \multirow{2}{*}{ Feed ingredients } & \multicolumn{3}{|c|}{$\begin{array}{l}\text { Maize choice feeding } \\
\text { MCF }\end{array}$} & \multirow{2}{*}{ MTMR $^{1}$} & \multicolumn{3}{|c|}{$\begin{array}{l}\text { Barley choice feeding } \\
\text { BCF }\end{array}$} & \multirow{2}{*}{ BTMR $^{1}$} \\
\hline & $0-4$ week & 5-8 week & overall & & $0-4$ week & $\frac{\text { DС }}{5-8 \text { week }}$ & overall & \\
\hline Barley & -- & -- & -- & -- & 190.5 & 271.6 & 222.5 & 255.9 \\
\hline Maize & 276.7 & 307.6 & 291.5 & 248.8 & -- & -- & -- & -- \\
\hline $\begin{array}{l}\text { Soyabean meal } \\
(44 \% \mathrm{CP})\end{array}$ & 98.3 & 175.0 & 136.5 & 130.4 & 129.4 & 146.1 & 138.2 & 103.7 \\
\hline Wheat bran & 356.2 & 278.4 & 318.0 & 201.2 & $394.8^{* \mathrm{a}}$ & $332.7^{* \mathrm{~b}}$ & $369.2^{*}$ & 221.0 \\
\hline Lucerne hay & $244.3^{*}$ & $213.4^{*}$ & $228.9^{*}$ & 400.0 & $261.3^{* a}$ & $224.4^{* b}$ & $245.5^{*}$ & 400.0 \\
\hline Salt & 8.7 & 9.1 & 8.9 & 7.0 & 8.6 & 9.1 & 8.8 & 7.0 \\
\hline Lime stone & 14.5 & 15.2 & 14.9 & 11.6 & 14.2 & 14.8 & 14.5 & 11.4 \\
\hline $\begin{array}{l}\text { Mineral-vitamin } \\
\text { premix }^{2}\end{array}$ & 1.3 & 1.3 & 1.3 & 1.0 & 1.2 & 1.3 & 1.3 & 1.0 \\
\hline
\end{tabular}

Chemical composition (DM basis), \%

\begin{tabular}{lcccccccc} 
dry matter & 88.8 & 88.6 & 88.7 & 88.9 & 89.3 & 89.2 & 89.3 & 89.4 \\
crude protein & 17.2 & 19.5 & 18.4 & 18.2 & 18.8 & 18.7 & 18.8 & 18.1 \\
crude fibre & $14.5^{* \mathrm{~B}}$ & $12.9^{*}$ & $13.7^{* \mathrm{~B}}$ & 18.8 & $16.0^{* \mathrm{aA}}$ & $14.5^{* \mathrm{~b}}$ & $15.4^{* \mathrm{~A}}$ & 19.5 \\
ADF & $16.7^{* \mathrm{~B}}$ & $15.2^{*}$ & $15.9^{* \mathrm{~B}}$ & 21.1 & $17.9^{* \mathrm{aA}}$ & $15.9^{* \mathrm{~b}}$ & $17.1^{* \mathrm{~A}}$ & 22.0 \\
NDF & 34.6 & 30.5 & 32.6 & 36.2 & $36.8^{* \mathrm{a}}$ & $32.9^{* \mathrm{~b}}$ & $35.1^{*}$ & 39.2 \\
$\mathrm{ME}, \mathrm{Mcal} / \mathrm{kg}$ & $2.70^{* \mathrm{~A}}$ & $2.74^{*}$ & $2.72^{*}$ & 2.56 & $2.62^{* \mathrm{bB}}$ & $2.69^{* \mathrm{a}}$ & $2.64^{*}$ & 2.56 \\
\hline
\end{tabular}

* denotes the difference between corresponding TMR and the diet selected by goat $(\mathrm{P}<0.05)$

$\mathrm{A}, \mathrm{B}$ denotes the difference among the diets selected by goat consuming different grain in the same period $(\mathrm{P}<0.05)$

a,b denotes the difference among the diets selected by the goats for the same grain sources in different periods $(\mathrm{P}<0.05)$

${ }^{1}$ MTMR and BTMR are isocaloric and isonitrogenic

2 each kg vitamin-mineral premix provides vit. A 8.000.000 IU; vit. $\mathrm{D}_{3} 1.000 .000 \mathrm{IU}$; mg: vit. E 30.000; Mn 50.000; Zn 50.000; Fe 50.000; Cu 10.000; Co 150; I 800 and Se 150

Ingredients and chemical compositions of the diets (TMRs) were presented in Table 1. The chemical composition was determined according to AOAC (1998). NDF and ADF were analysed using the method of Goering and Van Soest (1970). Metabolizable energy content of the diets was calculated based on the table values published by NRC (1981).

Liveweight change, milk yield and feed intake were determined weekly after the training period. Animals were milked by hand and milk samples were taken from morning milk and then milk fat was determined by the Gerber method. Milk samples were also analysed for dry matter, ash, milk protein, NPN, casein nitrogen according to AOAC (1998). True protein was calculated by subtracting NPN from total nitrogen, and whey protein was determined by subtracting casein 
from true protein. Lactose was obtained by subtracting fat plus protein from milk organic matter as described by Sanz Sampelayo et al. (1998).

Data obtained in the experiment were analysed by GLM procedure of SPSS (SPSS, 1999). The differences among treatments were separated by Duncan Multiple Range Test. The composition of the TMRs and the diet selected by the goats were compared by One-Sample t-test. Difference between the diets selected by goats in choice-fed groups was separated by t-test (SPSS, 1999).

\section{RESULTS}

The results obtained in the experiment showed that diet selection was affected by feeding period (1-4 vs 5-8 weeks) and source of grain (maize vs barley). The goats receiving feed ingredients as choice made a diet with lower crude fibre (CF), $\mathrm{ADF}$ and NDF contents by consuming higher amount of grain, soyabean meal, lower amount of wheat bran and lucerne hay during the period of 5-8 weeks when compared to the selection during the period of 1-4 weeks. The differences for wheat bran and lucerne hay contents of the diet selected were statistically significant $(\mathrm{P}<0.05)$ for the groups receiving barley as choice (Table 1$)$.

The diet selected by the goats in MCF group contained higher $(\mathrm{P}<0.05) \mathrm{ME}$, somewhat more maize $(\mathrm{P}>0.05)$ and wheat bran, and less $(\mathrm{P}<0.05)$ lucerne hay, crude fibre $(\mathrm{CF}), \mathrm{ADF}$ and somewhat less NDF $(\mathrm{P}>0.05)$ than the MTMR (Table $1)$. The diet chosen by the goats fed with $\mathrm{BCF}$ had higher $(\mathrm{P}<0.05) \mathrm{ME}$, wheat bran $(\mathrm{P}<0.05)$ and somewhat more soyabean meal $(\mathrm{P}>0.05)$, but less $(\mathrm{P}<0.05)$ lucerne hay, $\mathrm{CF}, \mathrm{ADF}, \mathrm{NDF}$ and somewhat less barley $(\mathrm{P}>0.05)$ than the BTMR.

Grain source affected the diet selection significantly $(\mathrm{P}<0.05)$. ME content in the first half of the study was higher for MCF, but CF and $\mathrm{ADF}$ content were lower for the MCF than BCF in the first half of the study and the entire experimental period. However the diets selected in the both groups had similar ME, CP and NDF contents at the end of the study.

Feeding methods had also significant effects on DM, CP, CF, ADF and NDF intakes, but not liveweight change, milk yield and milk composition. The goats in choice feeding groups consumed lower amount of $\mathrm{DM}(\mathrm{P}<0.05), \mathrm{ME}(\mathrm{P}<0.07)$, $\mathrm{CP}(\mathrm{P}<0.05)$ and fibre $(\mathrm{CF}, \mathrm{ADF}, \mathrm{NDF})$ in the $1-4$ week period of the study (Table 2). These differences for the ME and $\mathrm{CP}$ intake disappeared during the 5-8 weeks of the study. At the end of the study, the goats in choice feeding groups selected and consumed much lower fibre $(\mathrm{CF}, \mathrm{ADF}$, and $\mathrm{NDF}, \mathrm{P}<0.01)$ and $\mathrm{DM}(\mathrm{P}<0.06)$ than the TMR goats, but ME and CP intakes were similar for the both feeding methods.

Grain source and the interaction between feeding method and grain source had no significant effects on DM, ME, CP and fibre (CF, ADF and NDF) intakes, as 
TABLE 2

Dry matter and nutrient intakes, milk yield and composition of German Fawn $\times$ Hair crossbred goats fed with different grain source and feeding methods

\begin{tabular}{|c|c|c|c|c|c|c|c|c|}
\hline \multirow{2}{*}{ Item } & \multicolumn{2}{|c|}{ TMR } & \multicolumn{2}{|c|}{ Choice feeding } & \multirow{2}{*}{ SEM } & \multicolumn{3}{|c|}{ Effects } \\
\hline & barley & maize & barley & maize & & FM & GS & $\overline{F M x G S}$ \\
\hline \multicolumn{9}{|l|}{$1-4$ week } \\
\hline ILW, kg & 49.54 & 48.83 & 46.04 & 47.18 & 1.73 & NS & NS & NS \\
\hline LW change, g/day & 88.25 & 90.15 & 65.30 & 33.92 & 47.22 & NS & NS & NS \\
\hline DMI, kg/day & $2.37^{\mathrm{a}}$ & $2.31^{\mathrm{ab}}$ & $1.94^{\mathrm{b}}$ & $2.08^{\mathrm{ab}}$ & 0.11 & 0.02 & NS & NS \\
\hline MPE, DMI/milk yield & 0.51 & 0.53 & 0.66 & 0.58 & 0.06 & NS & NS & NS \\
\hline MEI, Mcal/day & 6.04 & 5.93 & 5.06 & 5.61 & 0.31 & 0.07 & NS & NS \\
\hline CPI, g/day & 429.3 & 421.9 & 358.8 & 359.6 & 23.5 & 0.02 & NS & NS \\
\hline $\mathrm{CFI}, \mathrm{kg} /$ day & $0.46^{\mathrm{a}}$ & $0.43^{\mathrm{a}}$ & $0.31^{\mathrm{b}}$ & $0.30^{\mathrm{b}}$ & 0.02 & 0.01 & NS & NS \\
\hline ADFI, kg/day & $0.52^{\mathrm{a}}$ & $0.48^{\mathrm{a}}$ & $0.34^{\mathrm{b}}$ & $0.35^{\mathrm{b}}$ & 0.02 & 0.01 & NS & NS \\
\hline NDFI, kg/day & $0.92^{\mathrm{a}}$ & $0.838^{\mathrm{ab}}$ & $0.71^{\mathrm{b}}$ & $0.72^{\mathrm{b}}$ & 0.037 & 0.01 & NS & NS \\
\hline milk yield, g/day & 1216.7 & 1248.3 & 1293.1 & 1215.9 & 129.0 & NS & NS & NS \\
\hline \multicolumn{9}{|l|}{ 5-8 week } \\
\hline LW change, g/day & 105.15 & 53.17 & 32.14 & 170.09 & 45.32 & NS & NS & NS \\
\hline DMI, kg/day & 2.24 & 2.13 & 1.82 & 2.08 & 0.14 & NS & NS & NS \\
\hline MPE, milk yield/DMI & 0.52 & 0.51 & 0.47 & 0.59 & 0.06 & NS & NS & NS \\
\hline MEI, Mcal/day & 5.73 & 5.47 & 4.90 & 5.70 & 0.41 & NS & NS & NS \\
\hline CPI, g/day & 407.2 & 389.0 & 339.4 & 405.5 & 32.7 & NS & NS & NS \\
\hline CFI, kg/day & 0.43 & 0.40 & 0.33 & 0.38 & 0.029 & NS & NS & NS \\
\hline ADFI, kg/day & $0.49^{\mathrm{a}}$ & $0.45^{\mathrm{ab}}$ & $0.33^{\mathrm{c}}$ & $0.38^{\mathrm{bc}}$ & 0.031 & 0.01 & NS & NS \\
\hline NDFI, kg/day & $0.88^{\mathrm{a}}$ & $0.77^{\mathrm{ab}}$ & $0.59^{\mathrm{c}}$ & $0.63^{\mathrm{bc}}$ & 0.047 & 0.01 & NS & NS \\
\hline milk yield, $\mathrm{g} /$ day & 1179.2 & 1112.2 & 914.3 & 1242.5 & 129.0 & NS & NS & NS \\
\hline \multicolumn{9}{|l|}{ Overall } \\
\hline LW change, g/day & 95.76 & 73.72 & 50.56 & 94.44 & 23.24 & NS & NS & NS \\
\hline DMI, kg/day & 2.30 & 2.22 & 1.88 & 2.08 & 0.12 & 0.06 & NS & NS \\
\hline MPE, milk yield/DMI & 0.51 & 0.52 & 0.59 & 0.59 & 0.05 & NS & NS & NS \\
\hline MEI, Mcal/day & 5.88 & 5.70 & 4.97 & 5.66 & 0.35 & NS & NS & NS \\
\hline CPI, g/day & 418.5 & 405.4 & 349.9 & 382.6 & 26.26 & NS & NS & NS \\
\hline CFI, kg/day & $0.45^{\mathrm{a}}$ & $0.41^{\mathrm{a}}$ & $0.28^{\mathrm{b}}$ & $0.28^{\mathrm{b}}$ & 0.021 & 0.01 & NS & NS \\
\hline ADFI, kg/day & $0.50^{\mathrm{a}}$ & $0.46^{\mathrm{a}}$ & $0.32^{\mathrm{b}}$ & $0.33^{\mathrm{b}}$ & 0.023 & 0.01 & NS & NS \\
\hline NDFI, kg/day & $0.90^{\mathrm{a}}$ & $0.80^{\mathrm{ab}}$ & $0.65^{\mathrm{c}}$ & $0.68^{\mathrm{bc}}$ & 0.046 & 0.01 & NS & NS \\
\hline milk yield, $g$ /day & 1197.9 & 1180.7 & 1103.6 & 1229.0 & 144.0 & NS & NS & NS \\
\hline \multicolumn{9}{|l|}{ Milk composition, \% } \\
\hline lactose & 3.91 & 3.49 & 3.63 & 3.43 & 0.15 & NS & NS & NS \\
\hline protein & 3.40 & 3.40 & 3.40 & 3.65 & 0.13 & NS & NS & NS \\
\hline fat & 3.17 & 3.03 & 2.83 & 2.87 & 0.12 & NS & NS & NS \\
\hline total solid & 11.33 & 10.79 & 10.58 & 10.72 & 0.19 & NS & NS & NS \\
\hline
\end{tabular}


TABLE 2

continued

\begin{tabular}{|c|c|c|c|c|c|c|c|c|}
\hline \multirow{2}{*}{ Item } & \multicolumn{2}{|c|}{ TMR } & \multicolumn{2}{|c|}{ Choice feeding } & \multirow{2}{*}{ SEM } & \multicolumn{3}{|c|}{ Effects } \\
\hline & barley & maize & barley & maize & & FM & GS & $\mathrm{FM} \times \mathrm{GS}$ \\
\hline \multicolumn{9}{|l|}{ Nitrogen fractions, $g / L$} \\
\hline total $\mathrm{N}$ & 5.33 & 5.33 & 5.33 & 5.72 & 0.21 & NS & NS & NS \\
\hline protein $\mathrm{N}$ & 4.95 & 4.90 & 4.97 & 5.30 & 0.20 & NS & NS & NS \\
\hline casein $\mathrm{N}$ & 3.86 & 3.76 & 3.97 & 3.81 & 0.16 & NS & NS & NS \\
\hline whey $N, g / L$ & 1.08 & 1.14 & 1.00 & 1.07 & 0.10 & NS & NS & NS \\
\hline NPN, g/L & 0.43 & 0.42 & 0.45 & 0.44 & 0.02 & NS & NS & NS \\
\hline protein N/total N, \% & 91.96 & 91.70 & 91.74 & 92.10 & 0.62 & NS & NS & NS \\
\hline casein N/total N, \% & 72.08 & 70.98 & 73.60 & 73.69 & 1.43 & NS & NS & NS \\
\hline
\end{tabular}

SEM: standard error of mean

a,b, c. means having the different superscript in the same row are significantly different $(\mathrm{P}<0.05)$

LW - liveweight, DMI- dry matter intake, MPE- milk production efficiency, MEI-metabolizable energy intake, CPI-crude protein intake, ADFI-acid detergent fibre intake, NDFI-neutral detergent fibre intake, FM-feeding method, GS-grain source

NS - P>0.05

well as on milk yield and milk lactose, protein, fat, total solid and nitrogen fractions (total N, protein N, casein N, whey N and NPN; Table 2) at the end of the study.

\section{DISCUSSION}

The diets selected by goats changed as the experiment was in progress. The choice fed goats decreased crude fibre (CF), ADF and NDF contents of the diets by consuming higher amount of grain, soyabean meal, lower amount of wheat bran and lucerne hay during the period of 5-8 weeks when compared to the selection during the period of 1-4 weeks. This was more prominent for the BCF groups. Similar results were also reported by Fedele et al. (2002) and Görgülü et al. (2003). Fedele et al. (2002) showed that lactating goats selected the diets differing in crude protein and starch content, but not NDF during dry, pregnancy and lactation periods. Similarly Görgülü et al. (2003) revealed that the goats having free access to feed ingredient tended to decrease roughage to concentrate ratio, $\mathrm{CF}$ and $\mathrm{CP}$ content of the diets and to increase the ME content as the experiment was in progress. The changes in diet preferences according to the experimental period in the present study could be a reflection of the changes in the environmental conditions according to the experimental periods. The ambient temperature and relative humidity were higher $\left(23^{\circ} \mathrm{C}\right.$ vs $28^{\circ} \mathrm{C}$ and 58 vs $\left.62 \%\right)$ in the second half of the experiment. It is well documented that ruminants increase concentrate and reduce roughage intakes to minimize heat increment in their bodies under high 
environmental temperature when concentrate and roughage are available as free choices (e.g., Görgülü et al., 1998).

The results also showed that the goats from the choice feeding groups made the diets containing about $24 \%$ roughage and $76 \%$ concentrate by selecting less lucerne, but higher concentrate, leading to less $\mathrm{CF}, \mathrm{ADF}, \mathrm{NDF}$ contents but higher ME content, than the goats fed with TMRs. Additionally, the goats in choice feeding groups replaced forage NDF by wheat bran NDF, while they decreased NDF content of the diets selected. However the choice fed goats did not suffer any metabolic problem due to low dietary total NDF and forage NDF during experiment. This could be explained by the changes in feeding behaviour (order of feed ingredient consumptions, intermeal interval, meal size and meal length, etc.) of the goats having free access to feed ingredients (Abijaoude et al., 2000; Görgülü et al., 2003) and pectin content of lucerne hay with high buffering capacity (Van Soest et al., 1991). Fedele et al. (2002) reported that choice fed goats did not exhibit any unusual intake, but selected the diets containing $74-85 \%$ concentrate with similar NDF content (40\%) throughout the experiment. Görgülü et al. (2003) revealed that the choice fed goats during preweaning period consumed higher amount of feed, energy and protein and exhibited better performance than those receiving TMR, but they selected a diet containing a similar roughage/concentrate ratio to the TMR. The contradiction for roughage contents of the diets selected by goats between the present (24/76) and previous studies (40/60, Görgülü et al., 2003) could be attributed to the differences in genotype, milk yield, lactation period and climatic conditions. The previous study (Görgülü et al., 2003) was carried out with high yielding (about $4 \mathrm{~kg}$ milk per day) Damascus goats at the beginning of lactation in autumn (relatively cool season), but the present study was conducted with moderate yielding $(1.2 \mathrm{~kg} /$ day $)$ goats in mid lactation under warm conditions (summer).

Choice feeding decreased CF, ADF, NDF and DM intakes, but not affected ME and CP intakes, milk yield and milk composition. Sauvant et al. (1991) reported that providing supplemental concentrate induced a concomitant decrease in roughage intake when goats fed with ad libitum roughage. Decrease in DMI of the choice feeding groups could be attributed to decrease in roughage, but increase in $\mathrm{ME}$ contents of the diets selected by goats. It is well known that consuming a ration with low fibre decrease ruminal $\mathrm{pH}$, leading to reduce $\mathrm{DMI}$ in ruminant animals (Nocek, 1997). Furthermore, decrease in DMI in choice fed goats may also be a reflection of energy satiety (Glimp et al., 1989), as the animals consume feed to meet their energy requirements (e.g., Forbes, 1983) unless there is any physical limitation in the stomach capacity.

Our results also showed that the grain source and feeding method $\mathrm{x}$ grain source interaction had no effect on DM, ME, CP, CF, ADF, NDF intakes. However, the diets selected by goats offered different grains as choice had different compositions. The diets selected by goats fed with barley as choice tended to 
contain higher wheat bran, lucerne hay, CF, ADF and NDF and lower ME than the diet selected by goats fed with maize. High preferences of the goats fed with barley for fibre sources, wheat bran and lucerne hay can be explaned by maintaining the rumen environment within certain physiological range (James and Kyriazakis, 2002; Morand-Fehr, 2003) due to highly degradable starch of barley. Although the choice fed goats changed their diet preferences, milk yield and milk composition were not affected by feeding methods, grain source and their interaction. Similar results for grain source were obtained by Hadjipanayioutou (2004) with Damascus goats, but contrasted with others who observed a decrease in feed intake (Herrara-Saldana et al., 1990; Yang et al., 1997) and milk yield (Casper et al., 1990) of dairy cows fed barley compared to maize. In fact, similar milk yield and composition is expected when the goats consumed similar amount ME and CP as it was observed in the present study. Accordingly, Giger et al. (1987), Morand Fehr et al. (1991) and Sanz Sampelayo et al. (1998) reported that milk production and composition of goats are mainly dependent upon energy balance of animal rather than the composition of the diet.

Despite the differences between the composition of the selected diets and TMR, the choice fed goats consumed similar ME and CP and exhibited similar milk yield and milk composition to the TMR goats. These findings suggested that dairy goats having free access to multiple choice giving opportunity to form balanced diets could make their diets to meet their nutrient requirements, supporting the explanation of Forbes (2001) who stated that animals have evolved with a powerful mechanism for matching intake to requirements when feed ingredients offered was capable of providing a balanced diets. In the present study, proper feed ingredients (grains for energy, wheat bran and lucerne for fibre and energy diluting material and soyabean meal for protein sources) were used to give chance to the goats to form a balanced diet.

The present study also showed that our goats consumed higher ME and $\mathrm{CP}$ than the values recommended by NRC (1981). This could suggest that nutrient requirements of German Fawn $\times$ Hair crossbred goats in mid lactation might be underestimated by NRC (1981). Similar finding was also reported in our previous study for high yielding suckling Damascus goats (Görgülü et al., 2003).

\section{CONCLUSIONS}

It could be concluded that goats having free access to multiple feed ingredients allowing a balanced diet could chose their diet to meet their nutrient requirements, and goats could change their feed ingredient preferences according to the available grain sources (barley vs maize). Goats could consume about $75 \%$ concentrate without suffering any metabolic problem by settling total NDF around $34 \%$. 


\section{ACKNOWLEDGEMENTS}

The authors wish to thank the staffs of the Dairy Goat Unit of the Faculty of Agriculture, University of Cukurova, for their technical assistance.

\section{REFERENCES}

Abijaoude J.A., Moran-Fehr P., Tessier J., Schmidely Ph., Sauvant D., 2000. Diet effect on the daily feeding behaviour, frequency and characteristics of meals in dairy goats. Livest. Prod.Sci. 64, 29-37

AOAC, 1998. Official Methods of Analysis, Association of Official Analytical Chemists. $16^{\text {th }}$ Edition. Washington, DC

Archimede H., Sauvant D., Herview J., Poncet C., Dorleans M., 1995. Digestive interactions in the ruminant: Relationships between whole tract and stomach evaluation. Anim. Feed Sci. Tech. $54,327-340$

Casper D.P., Schingothe D.J., Eisenbeisz W.A., 1990. Response of early lactation dairy cows fed diets varying in source of nonstructural carbohydrate and crude protein. J. Dairy Sci. 73, 1039-1050

Cerillo M.A., Russell J.R., Crump M.H., 1999. The effects of hay maturity and forage to concentrate ratio on digestion kinetics in goats. Small Ruminant Res. 32, 51-60

Fedele V., Claps S., Rubino R., Calandrelli M., Pilla A.M., 2002. Effect of free-choice and traditional feeding systems on goat feeding behaviour and intake. Livest. Prod. Sci. 74, 19-31

Forbes J.M., 1983. Physiology of regulation of food intake. In: J.A.F. Rook, P.C. Thomas (Editors). Nutritional Physiology of Farm Animals. Longman, USA

Forbes J.M., 2001. Consequences of feeding for future feeding. Comp. Biochem. Physiol. Part A $128,463-470$

Galyean M.I., Owen F.N., 1991. Effects of diet composition and level of feed intake on site and extend of digestion in ruminant. In: T. Tsuda, Y. Sasaki, R. Kawashima (Editors). Physiological Aspects of Digestion and Metabolism in Ruminants. Academic Press, San Diego, CA, pp. 483-513

Giger S., Sauvant D., Hervieu J., 1987. Influence of the kind of compound feed on goat milk production and composition. Ann. Zootech. 36, 334-335

Glimp H.A., Hart S.T., VonTungeln D., 1989. Effect of altering nutrient density (concentrate to roughage ratio) and restricting energy intake on rate, efficiency and composition of growing lambs. J. Anim. Sci. 67, 865-871

Goering H.K., Van Soest P.J., 1970. Forage Fiber Analyses (Apparatus, Reagents, Procedures, and Some Applications). Agric.Handbook No. 379. ARS-USDA. Washington, DC

Goetch A.L., Detweiler G., Sahlu T., Puchala R., Dawson L.J., 2001. Dairy goat performance with different dietary concentrate levels in late lactation. Small Ruminant Res. 41,117-125

Görgülü M., Güney O., Torun O., Özuyanık O., Kutlu H.R., 2003. An alternative feeding system for dairy goats: Effects of free-choice feeding on milk yield and milk composition in early lactation of Damascus goats. J. Anim. Feed Sci. 12, 33-44

Görgülü M., Kılıcalp N., Kutlu H.R., 1998. Influence of roughage/concentrate ratio on milk yield and milk composition. In: Book of Abstract of the $49^{\text {th }}$ Annual Meeting of the European Association for Animal Production. Warsaw (Poland), p. 192

Görgülü M., Kutlu H.R., Demir E., Öztürkcan O., Forbes J.M., 1996. Nutritional consequences of free choice among feed ingredients by Awassi lambs. Small Ruminant Res. 20, $23-29$ 
Hadjipanayiotou M., 2004. Replacement of barley grain for corn in concentrate diets fed to dairy Damascus goats at different frequencies. Small Ruminant Res. 51, 229-233

Herrera-Saldana R.E., Huber J.T., Poore M.H., 1990. Dry matter, crude protein, and starch degradability of five cereal grains. J. Dairy Sci. 73, 2386-2393

James S.M., Kyriazakis I., 2002. The effect of consumption of foods that differ in energy density and/or sodium bicarbonate supplementation on subsequent diet selection in sheep. Brit. J. Nutr. $88,81-90$

Morand-Fehr P., 2003. Dietary choices of goats at the trough. Small Ruminnat Res. 49, 231-239

Morand-Fehr P., Bas P., Blanchart G., Dacord R., Giger-Reverdin E., Gihad A., Hadjipanayiotou M., Mowen A., Remeuf F., Sauvant D., 1991. Influence of feeding on goat milk composition and technological characteristics. In: P. Morand-Fehr (Editor). Goat Nutririton. EAAP Publication, Wageningen, pp. 209-224

Nocek J. E., 1997. Bovine acidosis: implications on laminitis. J. Dairy Sci. 80, 1005-1028

NRC, 1981. Nutrient Requirements of Goat. National Academy Press, Washington, DC

Petit H.V., 2000. Effect of whole and rolled corn or barley on growth and carcass quality of lambs. Small Ruminant Res. 37, 293-297

Santini F.J., Lu C.D., Potchoiba M.J., Fernandez J.M., 1992. Dietary fiber and milk yield, mastication, digestion, and rate of passage in goats fed alfalfa hay. J. Dairy Sci. 75, 209-219

Sanz Sampelayo M.R., Perez L., Boza J., Amigo L., 1998. Forage of different physical form in the diets of lactating Granadina goats: Nutrient digestibility and milk production and composition. J. Dairy Sci. 81, 492-498

Sauvant D., Morand-Fehr P., Giger-Reverdin S., 1991. Dry matter intake of adult goats. In: P. MorandFehr (Editor). Goat Nutrition. EAAP Publication, Wageningen, pp.25-36

Schmidely P., Lloret-Pujol M., Bas P., Rouzeau A., Sauvant D., 1999. Influence of feed intake and source of dietary carbohydrate on metabolic response to propionate and glucose challenges in lactating goats. J. Dairy Sci. 82, 738-746

SPSS, 1999. Statistical Package for Social Sciences. Applications Guide (Base 10.0). SPSS Inc., Chicago, IL

Van Soest P.J., Robertson J.B., Lewis B.A., 1991. Methods for dietary fiber, neutral detergent fiber, and nonstarch polysaccharides in relation to animal nutrition. J. Dairy Sci. 74, 3583-3597

Yang W.Z., Beauchemin K.A., Farr B.I., 1997. Comparision of barley, hull-less barley, and corn in the concentrate of dairy cows. J. Dairy Sci. 80, 2885-2895

\section{STRESZCZENIE}

\section{Wpływ rodzaju ziarna i metod żywienia, wolny wybór paszy lub TMR, na wydajność i skład mleka mieszańców, niemiecka płowa $\mathrm{x}$ welnista, kóz w środkowym okresie laktacji}

Celem doświadczeń przeprowadzonych w środkowym okresie laktacji na kozach mieszańcach, niemiecka płowa $\times$ wełnista, było zbadanie czy kozy mogą wybierać pasze $\mathrm{z}$ dawek zadawanych do woli, czy preferują dawki w zależności od rodzaju ziarna oraz czy podawanie dawek na zasadzie wolnego wyboru paszy w porównaniu z TMR może powodować zmiany w produkcyjności i składzie mleka. Trzydzieści sześć kóz podzielono na 4 grupy doświadczalne, po 3 powtórzenia; doświadczenie trwało 9 tygodni włączając jeden tydzień okresu przygotowawczego w przypadku żywienia z wolnym wyborem paszy. Kozy grupy 1 żywione były do woli dawką TMR z jęczmieniem (BTMR), składającą się ze słomy z lucerny (40\%) i mieszanki treściwej (60) złożonej ze śrutowanego jęczmienia, śruty 
sojowej oraz otrąb pszennych; w grupie 2 zastosowano system wolnego wyboru paszy (BCF), stosując te same pasze jak w grupie 1; grupa - 3 - żywienie do woli TMR, z ziarnem kukurydzy (MTMR), o składzie podobnym jak w grupie 2, zastępując jęczmień kukurydzą (MCF).

Na podstawie otrzymanych wyników stwierdzono, że zastosowana metoda żywienia nie miała istotnego wpływu $(\mathrm{P}<0,06)$ na pobranie s.m., włókna $(\mathrm{P}<0,01)$, ADF i NDF $(\mathrm{P}<0,01)$, oraz że rodzaj ziarna i interakcja tych czynników nie miały istotnego wpływu na pobranie składników pokarmowych, wydajność i skład mleka oraz zmiany masy ciała. Diety wybierane przez kozy przy systemie MCF i BCF zawierały mniej lucerny lecz więcej otrąb pszennych nie odpowiadające im dawki TMR, przy czym rodzaj ziarna nie miał wpływu na „selekcję” dawek. „Wybrane” diety BCF zawierały więcej włókna niż odpowiadające im MCF.

$\mathrm{W}$ podsumowaniu stwierdzono, że kozy produkujące mleko mogą wybierać pasze z zadawanych im dawek zgodnie z zapotrzebowaniem na składniki pokarmowe oraz że mogą zjadać dużo paszy treściwej (75-77\%) bez problemów zdrowotnych. 